\title{
Determining the Return Volatility of Major Stock Markets Before and During the COVID-19 Pandemic by Applying the EGARCH Model
}

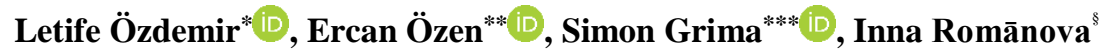

\begin{abstract}
With this study, we aim to determine the effect of the Covid-19 pandemic on the return volatility of the DJI, the DAX, the FTSE100 and the CAC40 stock indexes. We take return volatility between 1st January 2019 and 17th July 2020 and split it into two separate periods - before the Covid-19 pandemic outbreak and the first wave of the 'In-Pandemic' period. Only the so-called first wave of the pandemic was chosen to avoid the influence of knowledge of possible vaccines and antiviral solutions. Data were analysed by using the exponential GARCH (EGARCH) model. Findings show excessive volatility in the major stock markets with short volatility persistence and the presence of leverage in returns during the first wave of the Covid-19 pandemic outbreak. Moreover, during the pandemic period, positive shocks have been observed to have a greater effect than negative socks on the stock index return volatility.
\end{abstract}

Keywords: Corona Virus (COVID-19); pandemics; return volatility; stock indexes; EGARCH.

JEL classification: E44; G19; G41.

\section{INTRODUCTION}

COVID-19 is an infectious disease caused by a newly discovered coronavirus. As reported by the World Health Organization (WHO), most people infected with the COVID19 virus will experience mild to moderate respiratory illness and recover without requiring special treatment (World Health Organization, 2020). The first case of the coronavirus in China in December 2019 has quickly expanded into the global outbreak of the Covid-19 pandemics with more than half a million infected people and $16 \%$ of death cases on March, $20^{\text {th }}, 2020$ (Worldometer, 2020). The pandemic outbreak has affected all industries and the stock market around the world. The Covid-19 outbreak brought uncertainty and general distress, which caused the substantial decline of the Shanghai stock market by $8 \%$ on

\footnotetext{
*University of Afyonkocatepe, Turkey; e-mail: letifeozdemir@aku.edu.tr.

** University of Usak, Turkey; e-mail: ercan.ozen@usak.edu.tr.

**** University of Malta, Malta; e-mail: simon.grima@um.edu.mt (corresponding author).

${ }^{\S}$ University of Latvia, Latvia; e-mail: inna.romanova@lu.lv.
} 
February $3^{\text {rd }}, 2020$. This disruption rapidly spread to other international stock markets resulting in, for example, a decline in the US stock prices, including plummeting of the Standard \& Poor's 500 Index (S\&P index) and the Dow Jones Industrial Average Index (DJIA) by $4.4 \%$. Despite, many countries have ignored the rapid propagation of the virus at the beginning of 2020; the Covid -19 has started to raise serious concerns due to its rapid spread outside China (Albulescu, 2020a). Some analysts such as Elliot (2020) even saw the parallels to the crisis of 1929, noting that Covid-19 is "unprecedented", with record levels of leverage and overbought stocks. Chevallier (2020) suggested there will be a cataclysmic impact of the pandemics on the financial markets and expects a severe recession. Besides, the world real GDP growth in 2020 was revised by many institutions such as Goldman Sachs and IHS Markit to less than 2\% forecasting the possible global recession (Isaccs, 2020).

This uncertainty and panic in the markets have affected the stock market in different ways and despite the expected general plunge of major stock markets, other stocks, for example, Campbell Soup Company (CPB), Zoom Video Communications (ZM), Teladoc Health, Inc. (TDOC), Domino Pizza (DPZ), The Clorox Company (CLX), Virtu Financial, Inc. (VIRT) and Everbridge, Inc. (EVBG) benefited by providing an alternate market universe, defined by Desjardins (2020) as "The Pandemic Economy".

Although several studies have focussed on stock market volatility, the behaviour of investors in stock markets, price and return fluctuations, market trading volume and general behaviour of the world stock markets, this pandemic (Covid-19) has disrupted the world in an unprecedented manner and a study on the change in the return volatility of major stocks during this early distressed period would help in understanding the effect of the pandemic fear when the world is still uncertain of the outcome and pandemic fatigue has not yet kicked in (i.e. whether there will be a vaccine or antiviral medicine to ensure a quick return to normality).

\section{OBJECTIVE OF THE STUDY}

Therefore, following the topicality of the Covid-19 pandemic outbreak in the world the uncertainties during this "Pandemic Economy", we aim to determine the impact of the negative news of Covid-19 cases and deaths on the return volatility of the stock market indexes specifically, the DJIA, the Deutscher Aktienindex (DAX), the Financial Times Stock Exchange 100 Index (FTSE100) and the Cotation Assistee en Continue (CAC40). To identify the impact of the uncertainties following the pandemic outbreak, we study the periods before the pandemic period started in the United States of America (US) and Europe (from 1st January 2019 to the $31^{\text {st }}$ December 2019) and in the so-called first wave of the in-pandemic period ( $2^{\text {nd }}$ January 2020 to $17^{\text {th }}$ July 2020). The analysis of the impact of uncertainties following the pandemic outbreak on the major stock market indexes allows us to determine its' impact on the major stock markets representing the USA (DJIA), Germany (DAX), the UK (FTSE100) and the French (CAC40). The determination of the impact of uncertainty following the pandemics is important for both non-professional and professional investors, including, policymakers, portfolio and fund managers as well as risk managers, underwriters, actuaries, and other professionals who are responsible for the portfolio diversification and portfolio management decisions.

\section{LITERATURE REVIEW}

There is a growing literature that not only relates to past pandemics such as HIV/AIDS, SARS but opens up to the current, still ongoing COVID-19. However, only a few studies have 
placed their focus on the impact these pandemics have on the major markets. Pandemics such as HIV/AIDS affected economic units such as businesses, households and government, the labour supply decisions, labour efficiency and household income. Budgets deficits orphaned by AIDS increased in certain countries because of higher business costs, public expenditure on health care and support of disabled and children (Haacker, 2004). Kauffman and Weerapana (2006) and Daly, Batten, Mishra, and Choudhury (2019) demonstrated that the bad news related to HIV/AIDS in the Republic of South Africa had a negative effect on the exchange rate of the South African Rand against the U.S. Dollar. Lee and McKibbin (2004), demonstrated that the SARS epidemic affected significantly various economies, because of the reduction in the demand for various goods and services, increased operating costs and country risks, which in turn increased the risk premiums. This had an impact on a global scale in 2003 although the count of infected persons and deaths, in this case, was not the same in all countries.

According to Loh (2006), although, with no significant long-run implications the SARS pandemic increased the volatility in the airline stocks with lower mean returns in certain countries. Fernandes (2020), for example, explains that COVID-19 has a global effect and that this major difference from previous pandemics, is that this pandemic brings the world together, creating a spill-over effect throughout the supply chains and causing disruption in the balance of supply and demand. Moreover, he argues that some well-known companies have seen their stock prices fall drastically in a few days and shows that the US and British markets have seen their worst performance ever with over $25 \%$ and $35 \%$ downfall respectively. He continues to argue that the impact of Covid-19 is being underestimated and suggests that in a mild scenario, GDP will take a 3 to $5 \%$ hit depending on the country and that service-oriented and tourism reliant economies will specifically be negatively affected with the largest job losses.

Singh, Dhall, Narang, and Rawat (2020), using panel data analysed the impact of the COVID-19 outbreak on the stock markets of G-20 countries 150 days before and 58 days post the COVID-19 outbreak news release in the international media. They noted a cumulative average abnormal return during the first 43 days as a consequence of increased panic in the stock markets resulting from an increased number of COVID-19 positive cases. However, they note a recovery after that date.

Using the global hybrid Dynamic Stochastic General Equilibrium (DSGE) Models and Computable General Equilibrium (CGE) Models developed by McKibbin and Wilcoxen (1999, 2013), McKibbin and Fernando (2020), calculated the impact of the outbreak of Covid19 while still only in China, on the global economy. They show that this impact on the financial risk, even with a control in the United States (US) was higher in relation to the ( $2 * 21)$ G-20 and OECD countries and lower than England and several developing countries

Another study by Albulescu (2020a, 2020b) noted that following the outbreak of the COVID-19; the long-run price of crude oil was impacted negatively by the news of COVID19 infections and noted that there was an indirect effect on crude oil prices when the volatility of the financial markets is amplified.

Moreover, Bahrini and Filfilan (2020) found a negative response of the stock markets in the GCC (Gulf Cooperation Council) countries to the COVID-19 confirmed deaths. The analysis has shown that the daily returns of the major stock market indices in these countries have declined during the increasing number of confirmed deaths.

Zeren and Hizarci (2020), used data between January $23^{\text {rd }}, 2020$ and March $13^{\text {th }}, 2020$, to study the co-integration relationship between Covid-19 cases and some selected stock markets. They demonstrated the existence of a co-integration relationship between the Covid-19 cases 
and the Shanghai Stock Exchange (SSE), the Korea Composite Stock Price Index (KOSPI) and the Índice Bursátil Español (IBEX35) and no relationship with the FTSE 100, Milano Indice di Borsa (MIB), the CAC40 and the DAX30; which revealed that there is a geographical effect of Covid-19 on stock markets as the virus spread to the European countries during March.

Moreover, Ramelli and Wagner (2020b) demonstrate that the outbreak of Covid-19 in China and the US brought about increases in the returns of sectors related to Telecom Services, Health care and Software services and decreases in sectors such as energy, transportation, insurance, real estate, retailing and automobiles. They explained that the reaction to concerns related to Covid-19 by the Chinese and the US stock markets was swift due to investors' concern regarding corporate debt and liquidity, which was expected to mutate in an economic crisis augmented through financial channels (Ramelli \& Wagner, 2020a).

Kinateder, Campbell, and Choudhury (2021) showed that the Covid-19 pandemic similarly to the financial crises, created fear amongst investors. They found that gold, U.S., UK, and German sovereign bonds were considered as a safe option for investors during that period. Also, Hassan, Djajadikerta, Choudhury, and Kamran (2021) compared the safe-haven properties of various assets with the major Gulf Cooperation Council (GCC) stock indexes during two periods during the financial turmoil; specifically the COVID-19 pandemic and the 2008 Global Financial Crisis (GFC) periods. They found that sovereign bonds offered the highest hedging benefits under both crises. The traditional safe assets, gold and silver, which were reasonably productive under the GFC, have been less so during the pandemic. Moreover, they noted that the Japanese yen emerged as a safe choice for investors holding GCC stock indexes and that both sector indexes and stock indexes failed to safeguard investors most of the time during each crisis.

\section{METHODOLOGY}

To carry out this study we used the exponential GARCH (EGARCH) model developed by Nelson (1991). This since, although we could have used other models, such as the Autoregressive Conditional Heteroskedasticity (ARCH) model developed by Engle (1982) to understand better the dynamic properties of financial time series and for predicting heteroskedasticity over time and a later mode the GARCH (Generalized ARCH) model, developed by Bollerslev (1986), which is based on the weighting of past error squares; they assume the same effect on the volatility of financial assets for positive and negative shocks in the financial markets. In addition, these models, are only concerned with the magnitude of volatility, and the sign of volatility is ignored.

As noted by Black (1976), it is frequently observed in the financial markets that negative news (negative shocks) affect volatility more than positive news of the same size (positive shocks). This situation, which is expressed as the leverage effect, cannot be detected with ARCH/ GARCH models. The EGARCH model allows for a more appropriate analysis of the asymmetry effect in the volatility of the time series. The most important feature of this model is that it allows the modelling of asymmetric effects in estimates by eliminating the non-negative constraint in GARCH models. The EGARCH model proposed by Nelson (1991) is expressed as follows:

$$
\log \left(h_{t}\right)=\omega+\sum_{j=1}^{p} \beta_{j} \log \left(h_{t-j}\right)+\sum_{i=1}^{q} \alpha_{i} \frac{\left|u_{t-i}\right|}{\sqrt{h_{t-i}}}+\sum_{i=1}^{q} \gamma_{i} \frac{u_{t-i}}{\sqrt{h_{t-i}}}
$$


In the model, $\mathrm{h}_{\mathrm{t}}$ shows the conditional variance, $\mathrm{h}_{\mathrm{t}-\mathrm{j}}$ shows the values of the conditional variance going back $\mathrm{j}$ periods, $\mathrm{u}_{\mathrm{t}-\mathrm{i}}$ shows the values of the error terms going back i periods. $\omega$, $\beta_{\mathrm{j}}, \alpha_{\mathrm{i}}$ and $\gamma_{\mathrm{i}}$ are EGARCH model parameters. The presence of asymmetric volatility in the EGARCH model depends on the statistically significant $\gamma_{i}$ parameter. The $\gamma_{i}$ parameter shows both the leverage effect and the asymmetry of the series. In the model, if $\gamma_{i}=0$, it means that a positive shock and a negative shock have the same effect on volatility. If $\gamma_{i} \neq 0$, it indicates the presence of an asymmetric effect in the series. If $-1<\gamma_{i}<0$, a negative shock increases volatility more than a positive shock (Brooks, 2008, p. 406).

\section{DATA}

In the study, we studied the effect of the Covid-19 Pandemic on the stock market volatility of the DJIA, DAX, FTSE100 and CAC40 stock indices. The choice of this sample was based on the reasoning that the latter three markets are the most popular European stock market indexes, while the former market is representative of one of the most popular markets in the US. They are seen as a proxy for the broader market (Kuepper, 2020). The data set used in this study consists of daily closing price data from $1^{\text {st }}$ January 2019 to the 17 th July 2020 and was divided into two sub-periods: The pre-pandemic period - $1^{\text {st }}$ January 2019 to $31^{\text {st }}$ December 2019 and the in-pandemic period $2^{\text {nd }}$ January 2020 to $17^{\text {th }}$ July 2020 . This data was collected using the "www.investing.com" Logarithmic returns of stock indices calculated using the formula $\mathrm{R}_{\mathrm{t}}=\ln \left(\mathrm{P}_{\mathrm{t}} / \mathrm{P}_{\mathrm{t}-1}\right)$. Graphs during the period of study of the DJIA, DAX, FTSE100 and CAC40 returns are shown in Figures no. 1, 2, 3 and 4.

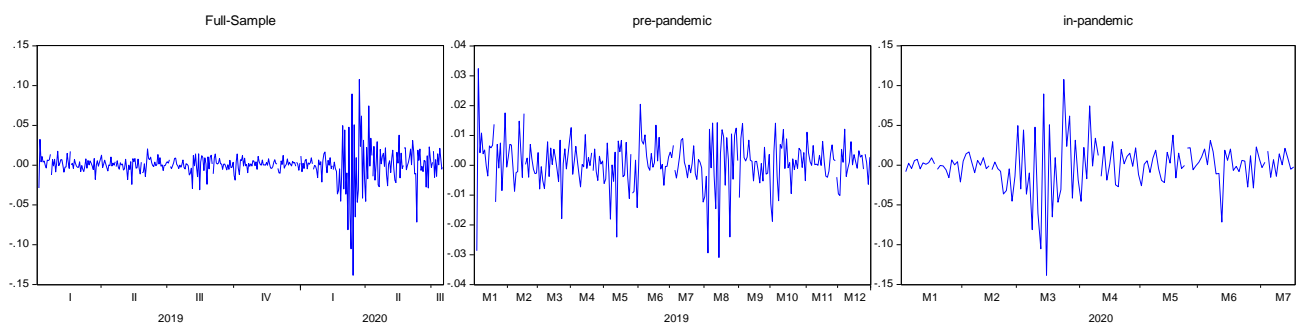

Figure no. 1 - Series of DJI return

Source: Authors' Compilation

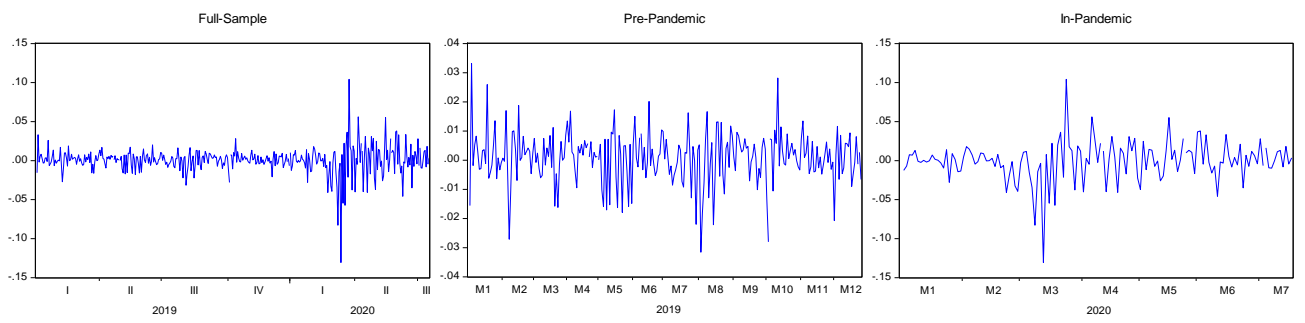

Figure no. 2 - Series of DAX return Source: Authors' Compilation 


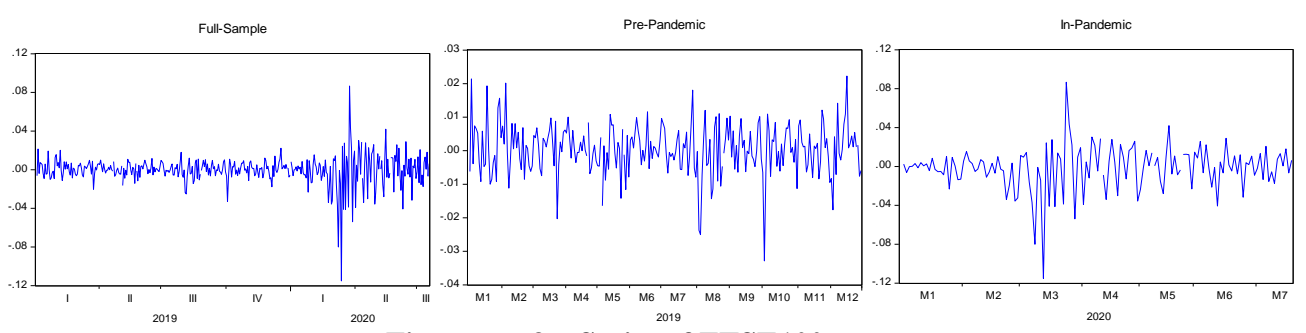

Figure no. 3 - Series of FTSE100 return

Source: Authors' Compilation
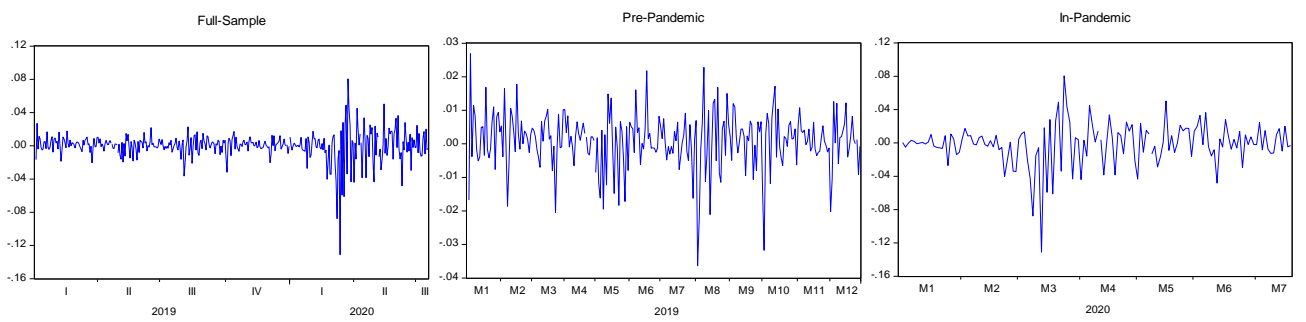

Figure no. 4 - Series of CAC40 return

Source: Authors' Compilation

When the figures of the stock index return are analysed, we note that there are fluctuations in all stock index returns shortly after the Covid-19 pandemic appears. This highlights that stock indices are affected by the Covid-19 pandemic. Descriptive statistics of the index return series are shown in Table no. 1.

Table no. 1 - Descriptive Statistics

\begin{tabular}{|c|c|c|c|c|c|c|c|c|}
\hline & Index & Mean & Std.Dev. & Skewness & Kurtosis & Jarque-Bera & ADF & PP \\
\hline \multirow{3}{*}{ DJIA } & Full-sample & -0.0003 & 0.0190 & -1.0107 & 17.7376 & $5577.442 * * *$ & $-6.5061 * * *$ & $-26.2288 * * *$ \\
\hline & Pre-Pandemic & 0.0008 & 0.0078 & -0.6639 & 6.2452 & $128.582 * * *$ & $-18.2644 * * *$ & $-18.1355 * * *$ \\
\hline & In-Pandemic & -0.0005 & 0.0303 & -0.6081 & 7.7544 & $136.478 * * *$ & $-7.6043 * * *$ & $-15.9014 * * *$ \\
\hline \multirow{3}{*}{ DAX } & Full-sample & 0.0005 & 0.0167 & -1.1438 & 17.8569 & $3653.071 * * *$ & $12 * * *$ & $-19.8595 * * *$ \\
\hline & Pre-Pandemic & 0.0009 & 0.0088 & -0 & 4.9097 & $43.2445 * * *$ & 51 *** & $-15.8821 * * *$ \\
\hline & In-Pandemic & -0.0003 & 0.0256 & -0.8 & 9.1539 & 231.106 *** & $-11.5472 * * *$ & $-11.6906^{* * * *}$ \\
\hline \multirow{3}{*}{ FTSE100 } & Full-s & -0.0001 & 0.0147 & -1. & 17.4323 & $3522.064 * * *$ & $0 * * *$ & $-20.1527 * * *$ \\
\hline & Pre-Pandemic & 0.0004 & 0.0074 & -0.4385 & 5.1494 & $56.592 * * *$ & $-13.8479 * * *$ & $-13.7254 * * *$ \\
\hline & In-Pan & -0.0013 & 0.0228 & -0.9607 & 8.4869 & $192.9337 * * *$ & $-12.2629 * * *$ & -12.2475 *** \\
\hline \multirow{3}{*}{ CAC40 } & Full-sample & -0.0001 & 0.0164 & -1.7575 & 17.3637 & $3580.785 * * *$ & $-6.1577 * * *$ & $-20.0508^{* * *}$ \\
\hline & Pre-Pandemic & 0.0009 & 0.0083 & -0.7382 & 5.5685 & $92.894 * * *$ & $-11.8731 * * *$ & $-15.5502 * * *$ \\
\hline & In-Pandemic & -0.0012 & 0.0252 & -1.1779 & 8.4933 & 205.4286 *** & $-11.8166 * * *$ & $-11.9299 * * *$ \\
\hline
\end{tabular}

Note: *** indicate respectively statistical significance at the 1 percent levels.

Source: Authors' compilation

According to the Jarque-Bera test statistics of the stock index return series in all periods, the series does not have a normal distribution. The rejection of the normality test based on the Jarque-Bera test provides evidence of the presence of GARCH effects. The Augmented DickeyFuller (ADF) unit root test developed by Dickey and Fuller (1979) and Phillips and Perron (PP) unit root test developed by Phillips and Perron (1988) were used for the stationary analysis of 
the series. The results of the unit root tests, both ADF and PP tests, showed that the series does not have unit root in all periods. The null hypothesis that the unit root exists in the series is therefore rejected. Thus, it is concluded that the level values of the series are stationary $\mathrm{I}(0)$.

\section{FINDINGS}

After determining that the stock index return series are stationary in the level values, we determined whether heteroskedasticity is present in the series to model the volatility of the series. We first determine the autoregressive moving average (ARMA) model structure, which is the linear stationary stochastic model of the return series. The most suitable ARMA models for return series are determined according to Akaike Information Criteria (AIC), Schwartz Information Criteria (SCI) and Log-Likelihood ratio and are shown in Table no. 2. The most suitable ARMA models of DJIA, DAX, FTSE100 and CAC40 stock index return series were determined separately in all periods. Then, autocorrelation and ARCH LM tests were performed until the 10th lag to determine whether there is heteroskedasticity in the return series. The results of the tests are provided in Table no. 2 .

Table no. 2. -ARMA Models

\begin{tabular}{|c|c|c|c|}
\hline & \multicolumn{3}{|c|}{ DJI } \\
\hline & Full-sample & Pre-Pandemic & In-Pandemic \\
\hline & $\operatorname{ARMA}(2,2)$ & $\operatorname{ARMA}(3,3)$ & $\operatorname{ARMA}(3,1)$ \\
\hline$A I C$ & -5.301545 & -6.853582 & -4.363217 \\
\hline SIC & -5.240292 & -6.755263 & -4.234717 \\
\hline Log Likelihood & 1034.500 & 867.1246 & 302.6987 \\
\hline$Q^{2}(10)$ & $398.44(0.000)$ & $30.240(0.001)$ & $87.265(0.000)$ \\
\hline \multirow[t]{4}{*}{$A R C H L M(10)$} & $19.18651(0.000)$ & $3.970879(0.001)$ & $5.085358(0.000)$ \\
\hline & \multicolumn{3}{|c|}{ DAX } \\
\hline & Full-sample & Pre-Pandemic & In-Pandemic \\
\hline & $\operatorname{ARMA}(3,2)$ & $\operatorname{ARMA}(0,0)$ & $\operatorname{ARMA}(3,1)$ \\
\hline$A I C$ & -5.376393 & -6.615534 & -4.513560 \\
\hline SIC & -5.304932 & -6.601448 & -4.385677 \\
\hline Log Likelihood & 1050.020 & 827.9417 & 315.1788 \\
\hline$Q^{2}(10)$ & $127.68(0.000)$ & $9.5287(0.483)$ & $37.569(0.000)$ \\
\hline \multirow[t]{4}{*}{$A R C H L M(10)$} & $12.55235(0.000)$ & $1.229649(0.2729)$ & $4.226727(0.0001)$ \\
\hline & \multicolumn{3}{|c|}{ FTSE100 } \\
\hline & Full-sample & Pre-Pandemic & In-Pandemic \\
\hline & $\operatorname{ARMA}(3,3)$ & $\operatorname{ARMA}(2,1)$ & $\operatorname{ARMA}(0,0)$ \\
\hline$A I C$ & -5.681309 & -6.971785 & -4.713642 \\
\hline SIC & -5.599953 & -6.901757 & -4.692328 \\
\hline Log Likelihood & 1115.855 & 883.4450 & 323.8845 \\
\hline$Q^{2}(10)$ & $144.67(0.000)$ & 4.8927(0.898) & $41.092(0.000)$ \\
\hline \multirow[t]{4}{*}{$A R C H L M(10)$} & $12.26871(0.000)$ & $0.557445(0.8474)$ & $3.893741(0.0001)$ \\
\hline & \multicolumn{3}{|c|}{ CAC40 } \\
\hline & Full-sample & Pre-Pandemic & In-Pandemic \\
\hline & $\operatorname{ARMA}(0,0)$ & $\operatorname{ARMA}(0,0)$ & ARMAO,0) \\
\hline$A I C$ & -5.378274 & -6.725962 & -4.511885 \\
\hline SIC & -5.368163 & -6.712036 & -4.490673 \\
\hline Log Likelihood & 1057.831 & 855.1972 & 312.3201 \\
\hline$Q^{2}(10)$ & $193.55(0.000)$ & $21.823(0.016)$ & $44.558(0.000)$ \\
\hline$A R C H L M(10)$ & $13.97479(0.000)$ & $1.888285(0.0476)$ & $3.473857(0.0005)$ \\
\hline
\end{tabular}


According to Ljung-Box $\mathrm{Q}^{2}$ statistics and ARCH LM test results, all return series were statistically significant until the $10^{\text {th }}$ lag, except for the pre-pandemic period of DAX and FTSE100 stock index returns. These findings show that there is heteroskedasticity in the return series, that is, an ARCH effect. At this stage, the volatility of the return series needs to be estimated.

For the most suitable EGARCH model estimation, we must first establish that parameters are statistically significant and parameter constraints provided. Then we must determine that the sum of the variance equation coefficients of conditional heteroskedasticity models are less than one. Among the models that meet these parameter criteria, the model with a low likelihood ratio (AIC), a Schwartz Information Criterion (SIC) and a log-likelihood ratio are chosen as the most suitable model.

The results of the EGARCH models determined as the most suitable model according to the criteria are given in Table no. 3 .

Table no. 3 - Results for EGARCH Models

\begin{tabular}{|c|c|c|c|c|c|c|}
\hline & \multicolumn{6}{|c|}{ DJIA } \\
\hline & \multicolumn{2}{|c|}{$\begin{array}{c}\text { Full-sample } \\
\text { EGARCH(1,1) }\end{array}$} & \multicolumn{2}{|c|}{$\begin{array}{l}\text { Pre-Pandemic } \\
\text { EGARCH }(1,1)\end{array}$} & \multicolumn{2}{|c|}{$\begin{array}{c}\text { In-Pandemic } \\
\text { EGARCH(1,1) }\end{array}$} \\
\hline & Coefficient & p-Value & Coefficient & p-Value & Coefficient & p-Value \\
\hline c & -0.402470 & 0.0032 & -0.245537 & 0.0000 & -0.668359 & 0.0149 \\
\hline$\alpha_{1}$ & 0.247458 & 0.0003 & -0.173856 & 0.0000 & 0.281471 & 0.0322 \\
\hline$\gamma$ & -0.175714 & 0.0000 & -0.276640 & 0.0000 & -0.178767 & 0.0633 \\
\hline$\beta_{1}$ & 0.975827 & 0.0000 & 0.964622 & 0.0000 & 0.939683 & 0.0000 \\
\hline \multicolumn{7}{|c|}{ Model İstatistic } \\
\hline$A I C$ & \multicolumn{2}{|c|}{-6.274387} & \multicolumn{2}{|c|}{-7.226801} & \multicolumn{2}{|c|}{-4.970345} \\
\hline SIC & \multicolumn{2}{|c|}{-6.223343} & \multicolumn{2}{|c|}{-7.156573} & \multicolumn{2}{|c|}{-4.863262} \\
\hline Log Likelihood & \multicolumn{2}{|c|}{1222.231} & \multicolumn{2}{|c|}{911.9635} & \multicolumn{2}{|c|}{342.9835} \\
\hline$Q^{2}(10)$ & \multicolumn{2}{|c|}{$10.404(0.406)$} & \multicolumn{2}{|c|}{$10,498(0.398)$} & \multicolumn{2}{|c|}{$3.3034(0.973)$} \\
\hline \multirow[t]{4}{*}{$\operatorname{ARCH~LM(10)}$} & \multicolumn{2}{|c|}{$0.926935(0.5082)$} & \multicolumn{2}{|c|}{$1,113746(0.3526)$} & \multicolumn{2}{|c|}{$0.290503(0.9822)$} \\
\hline & \multicolumn{6}{|c|}{ DAX } \\
\hline & \multicolumn{2}{|c|}{$\begin{array}{c}\text { Full-sample } \\
\text { EGARCH(1,1) }\end{array}$} & \multicolumn{2}{|c|}{ Pre-Pandemic } & \multicolumn{2}{|c|}{$\begin{array}{c}\text { In-Pandemic } \\
\operatorname{EGARCH}(1,1)\end{array}$} \\
\hline & Coefficient & p-Value & \multirow{5}{*}{\multicolumn{2}{|c|}{ There is no heteroskedasticity }} & Coefficient & p-Value \\
\hline c & -0.310972 & 0.0003 & & & -0.040173 & 0.0729 \\
\hline$\alpha_{1}$ & 0.151184 & 0.0002 & & & -0.168013 & 0.0025 \\
\hline$\gamma$ & -0.181040 & 0.0000 & & & -0.226907 & 0.0002 \\
\hline$\beta_{1}$ & 0.978318 & 0.0000 & & & 0.978807 & 0.0000 \\
\hline \multicolumn{7}{|c|}{ Model İstatistic } \\
\hline$A I C$ & \multicolumn{2}{|c|}{-5.992638} & & & -5.050 & \\
\hline SIC & -5.951 & & & & -4.965 & \\
\hline Log Likelihood & 1166. & & There is no $\mathrm{h}$ & dasticity & 349.9 & \\
\hline$Q^{2}(10)$ & 5.2499 & 874) & & & 16.134 & 096) \\
\hline ARCH LM(10) & 0.517790 & 8776) & & & 1.226430 & $.2815)$ \\
\hline & & & FT & & & \\
\hline & $\begin{array}{r}\text { Full-sa } \\
\text { EGARC }\end{array}$ & $\begin{array}{l}\text { ple } \\
(1,1) \\
\end{array}$ & Pre-P & & $\begin{array}{l}\text { In-Pan } \\
\text { EGARC }\end{array}$ & $\begin{array}{l}\text { mic } \\
(1,1) \\
\end{array}$ \\
\hline & Coefficient & p-Value & & & Coefficient & $\mathrm{p}$-Value \\
\hline c & -0.238076 & 0.0001 & & & -0.158380 & 0.0017 \\
\hline$\alpha_{1}$ & 0.077956 & 0.0030 & There is no $h$ & dasticity & -0.196420 & 0.0030 \\
\hline$\gamma$ & -0.161550 & 0.0000 & & & -0.244156 & 0.0000 \\
\hline$\beta_{1}$ & 0.980482 & 0.0000 & & & 0.958521 & 0.0000 \\
\hline & & & del İstatistic & & & \\
\hline$A I C$ & -6.286 & & & & -5.268 & \\
\hline
\end{tabular}




\begin{tabular}{|c|c|c|c|c|c|c|}
\hline$S I C$ & \multicolumn{2}{|c|}{-6.245696} & \multirow{2}{*}{\multicolumn{2}{|c|}{ There is no heteroskedasticity }} & \multicolumn{2}{|c|}{-5.183543} \\
\hline Log Likelihood & \multicolumn{2}{|c|}{1229.843} & & & \multicolumn{2}{|c|}{364.9126} \\
\hline$Q^{2}(10)$ & \multicolumn{2}{|c|}{$5.7663(0.835)$} & & & \multicolumn{2}{|c|}{$13.327(0.206)$} \\
\hline \multirow[t]{4}{*}{ ARCH LM(10) } & \multicolumn{2}{|c|}{$0.567411(0.8405)$} & & & \multicolumn{2}{|c|}{$1.053565(0.4039)$} \\
\hline & \multicolumn{6}{|c|}{ CAC40 } \\
\hline & \multicolumn{2}{|c|}{$\begin{array}{c}\text { Full-sample } \\
\text { EGARCH(1,1) }\end{array}$} & \multicolumn{2}{|c|}{$\begin{array}{l}\text { Pre-Pandemic } \\
\text { EGARCH(1,1) }\end{array}$} & \multicolumn{2}{|c|}{$\begin{array}{c}\text { In-Pandemic } \\
\text { EGARCH(1,1) }\end{array}$} \\
\hline & Coefficient & p-Value & Coefficient & p-Value & Coefficient & p-Value \\
\hline $\mathbf{c}$ & -0.421153 & 0.0020 & -1.391017 & 0.0002 & -0.136783 & 0.0000 \\
\hline$\alpha_{1}$ & 0.211022 & 0.0007 & 0.123073 & 0.0378 & -0.257051 & 0.0000 \\
\hline$\gamma$ & -0.205228 & 0.0000 & -0.345931 & 0.0000 & -0.305154 & 0.0000 \\
\hline$\beta_{1}$ & 0.970653 & 0.0000 & 0.868100 & 0.0000 & 0.955040 & 0.0000 \\
\hline \multicolumn{7}{|c|}{ Model İstatistic } \\
\hline$A I C$ & \multicolumn{2}{|c|}{-6.237952} & \multicolumn{2}{|c|}{-6.889834} & \multicolumn{2}{|c|}{-5.163292} \\
\hline$S I C$ & \multicolumn{2}{|c|}{-6.187394} & \multicolumn{2}{|c|}{-6.834128} & \multicolumn{2}{|c|}{-5.078444} \\
\hline Log Likelihood & \multicolumn{2}{|c|}{1230.758} & \multicolumn{2}{|c|}{879.0089} & \multicolumn{2}{|c|}{360.2672} \\
\hline$Q^{2}(10)$ & \multicolumn{2}{|c|}{$4.2291(0.936)$} & \multicolumn{2}{|c|}{$5.1303(0.882)$} & \multicolumn{2}{|c|}{$12.616(0.246)$} \\
\hline$A R C H L M(10)$ & \multicolumn{2}{|c|}{$0.410347(0.9415)$} & \multicolumn{2}{|c|}{$0.514933(0.8788)$} & \multicolumn{2}{|c|}{$1.159263(0.3253)$} \\
\hline
\end{tabular}

Source: Authors' Compilation

The parameters of the EGARCH models estimated for the return series are statistically significant. $\alpha$ represents the ARCH parameter, $\beta$ represents the GARCH parameter and $\gamma$ represents the leverage parameter in the model.

Large values of the ARCH and GARCH parameters influence conditional volatility in different ways. A high ARCH parameter implies that the effects of a shock are more pronounced in the subsequent period. In contrast, a high GARCH parameter implies that the effects of a shock are more persistent (Enders, 2004, p. 134). Therefore, the large ARCH value will increase volatility in the short term, and the large GARCH value will increase volatility in the long term (Nazlioglu, Erdem, \& Soytas, 2013). In the EGARCH model, the effect of good news on volatility in the financial markets is calculated as $\alpha+\gamma$, and the effect of bad news on volatility in the financial markets is calculated as $\alpha-\gamma$ (Lin, 2017). To determine how many days the volatility of the financial time series continues, the HL (Half-Life) measure can be determined based on the equation $\mathrm{HL}=\ln (0.5) / \ln (\beta)$ (Kalayc1, Demir, \& Gök, 2010).

The status of DJIA, DAX, FTSE100 and CAC40 stock index return volatility in all periods is shown in Table no. 4.

Table no. 4 - Volatility Status of Stock Index Returns in All Periods

\begin{tabular}{|c|c|c|c|c|}
\hline & Index & $\begin{array}{c}\text { The Effect of Good News } \\
\text { on Volatility }(\alpha+\gamma)\end{array}$ & $\begin{array}{c}\text { The Effect of Bad News on } \\
\text { Volatility }(\alpha-\gamma)\end{array}$ & $\begin{array}{c}\text { Volatility } \\
\text { Persistence (HL) }\end{array}$ \\
\hline \multirow{3}{*}{ DJIA } & Full-sample & 0.0714 & 0.4232 & 28.33 days \\
\hline & Pre-Pandemic & -0.4505 & 0.1027 & 19.24 days \\
\hline & In-Pandemic & 0.1027 & 0.4602 & 11.14 days \\
\hline \multirow{3}{*}{ DAX } & Full-sample & -0.0298 & 0.3322 & 31.62 days \\
\hline & Pre-Pandemic & \multicolumn{3}{|c|}{ There is no heteroskedasticity } \\
\hline & In-Pandemic & -0.3949 & 0.0589 & 32.35 days \\
\hline \multirow{3}{*}{ FTSE100 } & Full-sample & -0.0836 & 0.2395 & 35.17 days \\
\hline & Pre-Pandemic & \multicolumn{3}{|c|}{ There is no heteroskedasticity } \\
\hline & In-Pandemic & -0.4406 & 0.0477 & 16.36 days \\
\hline \multirow{3}{*}{ CAC40 } & Full-sample & 0.0058 & 0.4163 & 23.27 days \\
\hline & Pre-Pandemic & -0.2229 & 0.4690 & 4.90 days \\
\hline & In-Pandemic & -0.5622 & 0.0481 & 15.06 days \\
\hline
\end{tabular}

Source: Authors' Compilation 
EGARCH models predicted for the DJIA, the DAX, the FTSE100 and the CAC40 stock index returns show the presence of leverage in the returns.

For the DJIA, the DAX, the FTSE100 and the CAC40 index returns, it was determined that good news in the stock market positively affects the return volatility by $7.14 \%$, and bad news positively affects the return volatility by $42.32 \%$. When the DJIA index return volatility persistence was examined, it was determined that the effect of volatility continued for approximately 28 days. In the 'Pre-Pandemic period', one could note that good news in the stock market negatively affected the DJIA index return volatility by $45.05 \%$ and positively affected the DJIA index return volatility by $10.27 \%$. On the other hand, in the 'In-Pandemic' period good news positively affected the DJIA index return volatility by $10.27 \%$ and bad news by $46.02 \%$. When the DJIA index return volatility permanence is examined, it is determined as 19 days in the Pre-Pandemic period and 11 days in the In-Pandemic period.

For the DAX index returns, it was determined that good news in the stock market negatively affects the return volatility by $2.98 \%$, and bad news positively affects the return volatility by $33.22 \%$. When the DAX index return volatility persistence was examined, it was determined that the effect of volatility continued for approximately 32 days. In the 'InPandemic period', it was observed that good news in the stock market negatively affected the DAX index return volatility by $39.49 \%$, and the bad news positively affected the return volatility by $5.89 \%$. When the volatility permanence of the DAX index return was examined, it was determined as approximately 32 days in the In-Pandemic period.

For the FTSE100 index returns, one could note that good news in the stock market negatively affects the return volatility by $8.36 \%$, and bad news positively affects the return volatility by $23.95 \%$. When the FTSE 100 index return volatility persistence was examined, it was determined that the effect of volatility continued for approximately 35 days. In the 'InPandemic period', it was observed that good news in the stock market negatively affected the FTSE100 index return volatility by $44.06 \%$, and the bad news positively affected the return volatility by $4.77 \%$. When the volatility permanence of the FTSE100 index return is examined, it is determined as approximately 16 days in the In-Pandemic period.

For the CAC40 index returns, one could note that good news in the stock market positively affects the return volatility by $0,58 \%$, and bad news positively affects the return volatility by $41.63 \%$. When the CAC 40 index return volatility persistence was examined, it was determined that the effect of volatility continued for approximately 23 days. Moreover, one could note that good news in the stock market negatively affected the CAC40 index return volatility by $22 \%$ in the 'Pre-Pandemic' period and by $56.22 \%$ in the 'In-Pandemic period'. In addition, it was found that bad news positively affected the CAC40 index return volatility by $46.90 \%$ in the 'Pre-Pandemic' period and by $4.81 \%$ in the 'In-Pandemic' period. When the CAC40 index return volatility permanence is examined, it is determined as 5 days in the PrePandemic period and 15 days in the In-Pandemic period.

Diagnostic test statistics of EGARCH models are also included in Table no. 4. As a result of the predicted EGARCH models, the ARCH-LM test was conducted again to see if the $\mathrm{ARCH}$ effect in the return series disappeared. The ARCH-LM test statistic values calculated until the $10^{\text {th }}$ lag are found to be statistically insignificant and the conditional variance effect in the series disappeared.

No autocorrelation problem was found when examining autocorrelation in the model series using the Ljung-Box $\mathrm{Q}^{2}$ test until the $10^{\text {th }}$ lag. The graphics of the return volatility series obtained as a result of EGARCH models are shown below (Figures no. 5 to 8). By looking at 
the figures, it can be noted that the return volatility of major stock indexes has increased since the second month of the Covid-19 Pandemic period. At the start of the Covid-19 pandemic period, investors did or could not predict that the epidemic would spread rapidly and affect the markets. However, later, once the Covid-19 pandemic spread rapidly all over the world and uncertainty increased, volatility in the markets increased as a result.
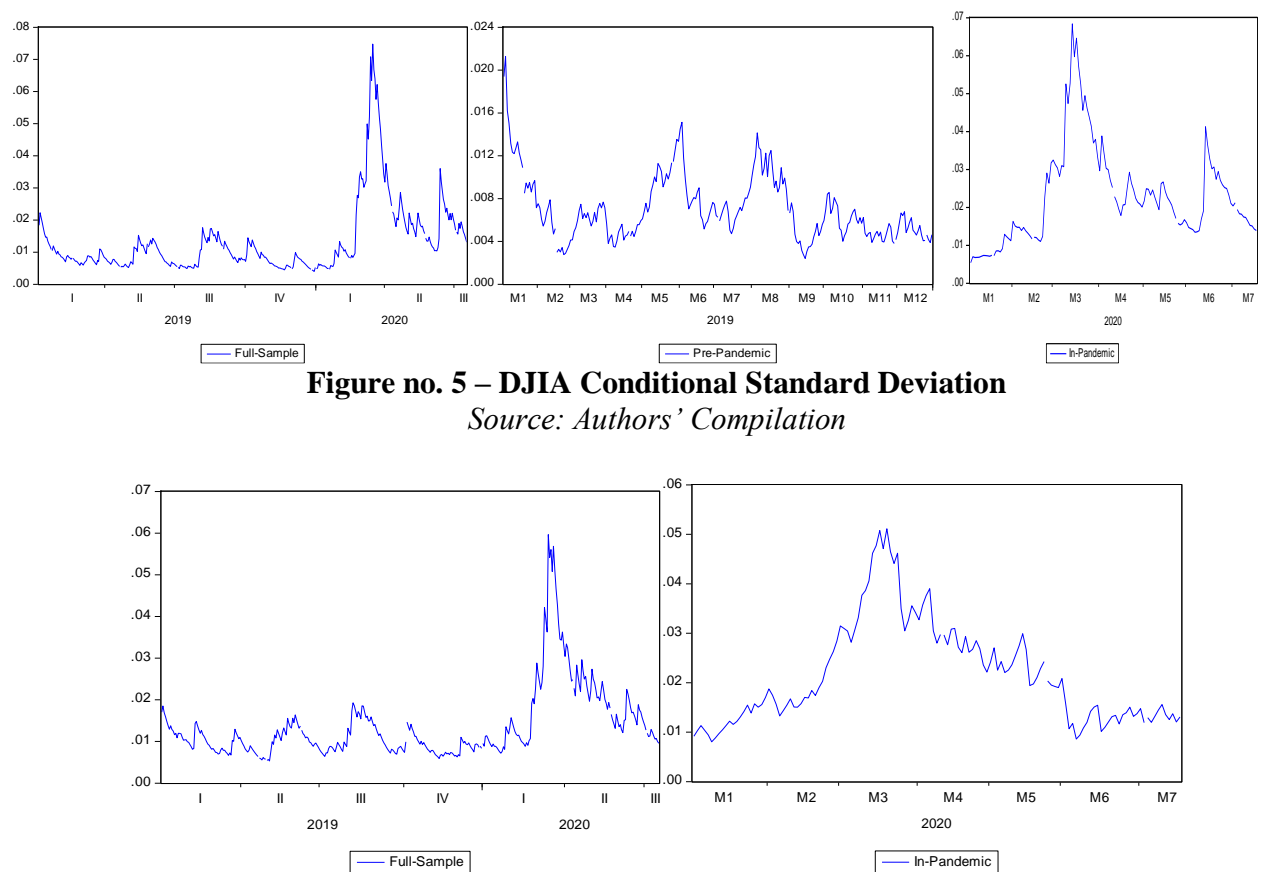

Figure no. 6 - DAX Conditional Standard Deviation

Source: Authors' Compilation

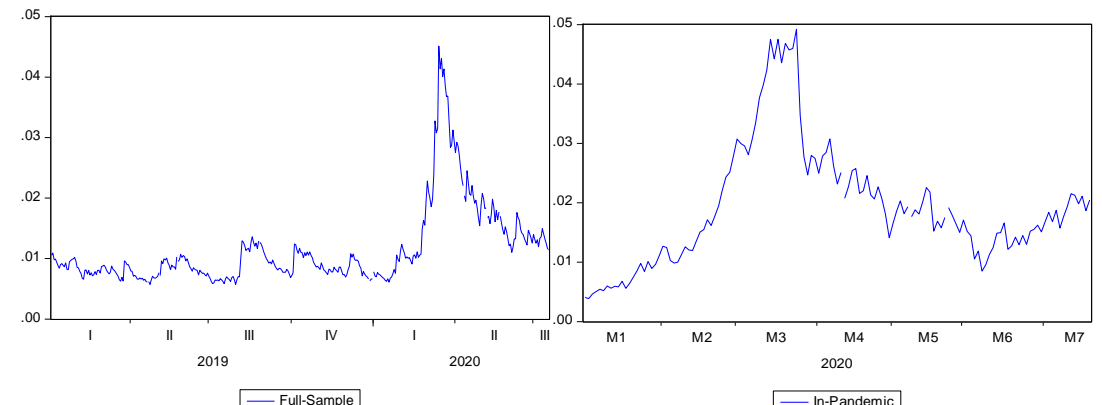

Figure no. 7 - FTSE100 Conditional Standard Deviation Source: Authors' Compilation 


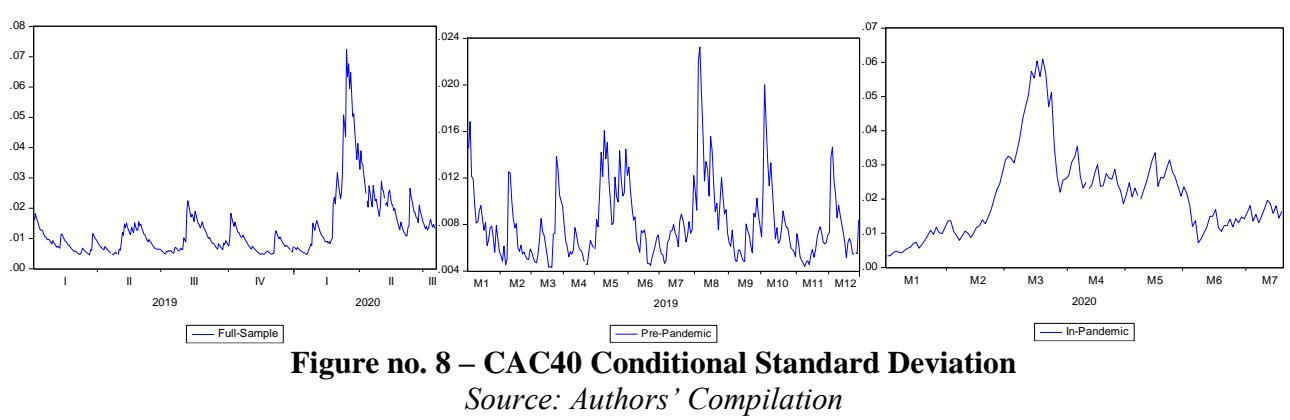

\section{CONCLUSION}

As noted throughout history, disruptions of the norm by epidemics and economic crises have left an impact on community life. However, the disruptions caused by the Covid-19 pandemic seems to be much worse and far more devastating, maybe due to its global effect and the speed with which it is spreading, which might be a consequence of the new societal cultures and the ease of global travel.

Decreasing world trade and almost extinct tourism activities have minimized commercial activities in almost all countries. In this process, many businesses are closed and unemployment is on the rise. In the latest developments in the world economy, it has been determined that production has decreased and unemployment rates have increased in various countries and country groups. For example, it is stated that the US unemployment rate rose from $7.2 \%$ to $8.4 \%$, and the unemployment rate in Japan rose from 5\% to $6.1 \%$ (Presidency of the Republic of Turkey \& Strategy and Budget Directorate, 2021). This affects financial markets expectations causing significant price fluctuations. Investors are facing volatility resulting from this new risk. Investors are facing volatility resulting from this new risk.

Our findings show that good news that flows to the markets during the 'Pre-Pandemic' period will reduce the volatility in the DJIA and the CAC40 indexes. However, during the 'In-Pandemic period', the good news, except in the case of the DJIA, created effects that reduce the volatility of the DAX, the FTSE100 and the CAC40 indexes. Moreover, although, volatility permanence decreased during the 'In-Pandemic' period except in the case of the DAX, volatility that occurs when bad news comes to the markets during this period is higher than in other periods. The reason for this may be the speed with which global news travels.

We also find that the Covid-19 pandemic increased the return volatility of all stock markets especially following the second month (February 2020) of the 'In-Pandemic' period. However, the volatility permanence during this period was short and the predicted EGARCH models show the presence of leverage in the returns. Also, during the 'In-Pandemic' period, good news has been observed to affect the stock index return volatility more than bad news except in the case of the DJIA index, with good news in the markets further reducing the stock return volatility of the DAX, the FTSE100 and the CAC40 during the 'In-Pandemic' period. The latter can be due to the positive effect of the mitigation measures taken by the economic administrators of the various countries and the rapid flow of information/news.

Although we were unable to find many studies to enable comparison may be due to these studies being at an early stage of the Covid-19 spread, our findings confirm and can be corroborated to the findings by Albulescu (2020a), Fernandes (2020), Ramelli and Wagner 
(2020a) and Zeren and Hizarci (2020). However, we feel that it is important at this stage to provide some insight for investors trading in the financial markets, risk managers, actuaries, policymakers and portfolio managers to see the volatility change during this pandemic period and the volatility response of the market following news on the pandemic. The findings have also important implications for policymakers, academics and other interested people and institutions.

\section{ORCID}

Letife Özdemir (D) https://orcid.org/0000-0002-8636-2277

Ercan Özen iD https://orcid.org/0000-0002-7774-5153

Simon Grima (iD https://orcid.org/0000-0003-1523-5120

Inna Romānova (iD https://orcid.org/0000-0002-0935-7749

\section{References}

Albulescu, C. (2020a). Coronavirus and Financial Volatility: 40 Days of Fasting and Fear. SSRN. Retrieved from https://ssrn.com/abstract=3550630 http://dx.doi.org/10.2139/ssrn.3550630

Albulescu, C. (2020b). Coronavirus and oil price crash: A note. arXiv. Retrieved from https://arxiv.org/ftp/arxiv/papers/2003/2003.06184.pdf

Bahrini, R., \& Filfilan, A. (2020). Impact of the novel coronavirus on stock market returns: Evidence from GCC countries. Quantitative Finance and Economics, 4(4), 640-652. http://dx.doi.org/10.3934/QFE.2020029

Black, F. (1976). Studies of Stock Price Volatility Changes. Proceedings of the American Statistical Association, Business and Economics Statistics Section, 177-181.

Bollerslev, T. (1986). Generalized Autoregressive Conditional Heteroskedasticity. Journal of Econometrics, 31(3), 307-327. http://dx.doi.org/10.1016/0304-4076(86)90063-1

Brooks, C. (2008). Introductory Econometrics for Finance: Cambridge University Press. http://dx.doi.org/10.1017/CBO9780511841644

Chevallier, J. (2020). COVID-19 Pandemic and Financial Contagion. Journal of Risk Financial Management, 13(2).

Daly, K., Batten, J. A., Mishra, A. V., \& Choudhury, T. (2019). Contagion risk in global banking sector. Journal of International Financial Markets, Institutions and Money, 63, 101136. http://dx.doi.org/10.1016/j.intfin.2019.101136

Desjardins, J. (2020). The Pandemic Economy: Which Stocks are Weathering the Storm? . Visual Capitalist. Retrieved from https://www.visualcapitalist.com/the-pandemic-economy-whichstocks-are-weathering-the-storm/

Dickey, D. A., \& Fuller, W. A. (1979). Distribution of the estimator for autoregressive time series with a unit root. Journal of the American Statistical Association, 74, 427-431.

Elliot, S. (2020). Analyst anticipates 'worst' financial crisis since 1929 amid fears of a global recession. CNBC economy. Retrieved from https://www.cnbc.com/2020/03/20/analyst-anticipates-worstcrisis-since-1929-amid-recession-fears.html

Enders, W. (2004). Applied Econometric Time Series. Hoboken, NJ: John Wiley and Sons, Inc.

Engle, R. F. (1982). Autoregressive Conditional Heteroscedasticity with Estimates of the Variance of United Kingdom Inflation. Econometrica, 50(4), 987-1008. http://dx.doi.org/10.2307/1912773

Fernandes, N. (2020). Economic Effects of Coronavirus Outbreak (Covid-19) on the World Economy. SSRN. Retrieved from https://ssrn.com/abstract=3557504 http://dx.doi.org/10.2139/ssrn.3557504

Haacker, M. (2004). The Macroeconomics of HIV/AIDS: IMF. 
Hassan, M. K., Djajadikerta, H. G., Choudhury, T., \& Kamran, M. (2021). Safe havens in Islamic financial markets: COVID-19 versus GFC. Global Finance Journal, in press, 100643. http://dx.doi.org/10.1016/j.gfj.2021.100643

Herron, J., \& Hajric, V. (2020). The Market's in Panic Mode.' Stock Markets Plunge 12\% Amid Coronavirus Fears. Time. Retrieved from https://time.com/5803847/coronavirus-stocks-fall/

Isaccs, S. (2020). Deutsche Bank: Coronavirus may impact financial Targets. $C N B C$. Retrieved from https://www.cnbc.com/video/2020/03/20/coronavirus-worst-market-crisis-since-greatdepression-strategist.html

Kalayc1, S., Demir, Y., \& Gök, İ. Y. (2010). Return volatility-trading volume relationship: an empirical application on Turkish derivatives exchange. Mediterranean Journal of Faculty of Economics and Administrative Sciences, 104-120.

Kauffman, K., \& Weerapana, A. (2006). The Impact of AIDS-related news on exchange rates in South Africa. Economic Development and Cultural Change, 54(2), 349-368. http://dx.doi.org/10.1086/497009

Kinateder, H., Campbell, R., \& Choudhury, T. (2021). Safe haven in GFC versus COVID-19: 100 turbulent days in the financial markets. Finance Research Letters, 101951 http://dx.doi.org/10.1016/j.frl.2021.101951

Kuepper, J. (2020). What are the FTSE 100, DAX and CAC40? Definition and Examples of the FTSE 100, DAX, and CAC 40. The balance. Retrieved from https://www.thebalance.com/what-are-theftse-100-dax-and-cac-40-1979168

Lee, J. W., \& McKibbin, W. J. (2004). Estimating the global economic costs of SARS Learning from SARS: preparing for the next disease outbreak: workshop summary, Institute of Medicine, Board on Global Health, Forum on Microbial Threats (pp. 92-109): National Academies Press.

Lin, Z. (2017). Modelling and forecasting the stock market volatility of SSE Composite Index using GARCH models. Future Generation Computer Systems. http://dx.doi.org/DOI:10.1016/j.future.2017.08.033

Loh, E. (2006). The impact of SARS on the performance and risk profile of airline stocks. Internationa Journal of Transport Economics. Rivista Internazionale di Economia dei Trasporti, 33(3), 401422.

McKibbin, W., \& Fernando, R. (2020). The global macroeconomic impacts of COVID-19: Seven scenarios. Centre for Applied Macroeconomic Analysis, Centre for Applied Macroeconomic Analysis (CAMA) Working Paper, 19.

McKibbin, W., \& Wilcoxen, P. (1999). The Theoretical and Empirical Structure of the GCubed Model. The Theoretical and Empirical Structure of the GCubed Model, 16(1), 123-148.

McKibbin, W., \& Wilcoxen, P. (2013). A Global Approach to Energy and the Environment: The Gcubed Model: North Holland. http://dx.doi.org/10.1016/B978-0-444-59568-3.00015-8

Nazlioglu, S., Erdem, C., \& Soytas, U. (2013). Volatility spillover between oil and agricultural $\begin{array}{llll}\text { commodity } \quad \text { Energy } & \text { Economics, } & 36, & 658-665\end{array}$ http://dx.doi.org/10.1016/j.eneco.2012.11.009

Nelson, D. B. (1991). Conditional heteroskedasticity in Asset Returns: A New Approach. Econometrica, 59(2), 347-370. http://dx.doi.org/10.2307/2938260

Phillips, P., \& Perron, P. (1988). Testing for a unit root in time series regression. Biometrika, 75(2), 335346. http://dx.doi.org/10.1093/biomet/75.2.335

Presidency of the Republic of Turkey, \& Strategy and Budget Directorate. (2021). Dünya Ekonomisindeki Son Gelişmeler Bülteni. Latest Developments in the World Economy Bulletin (Türkiye Cumhuriyeti Cumhurbaşkanliğı Strateji ve Bütçe Başkanlı̆̆ı), 2021/1. Retrieved from www.sbb.gov.tr/wp-content/uploads/2021/06/Dunya-Ekonomisinde-Son-Gelismeler-2021-Yili1-Ceyrek.pdf

Ramelli, S., \& Wagner, A. F. (2020a). Feverish Stock Price Reactions to COVID-19. Review of Corporate Finance Studies, 622-655. Retrieved from https://papers.ssrn.com/sol3/Papers.cfm?abstract_id=3550274 
Ramelli, S., \& Wagner, A. F. (2020b). What the stock market tells us about the consequences of COVID19. Mitigating the COVID Economic Crisis: Act Fast and Do Whatever It Takes. Retrieved from https://voxeu.org/article/what-stock-market-tells-us-about-consequences-covid-19

Singh, B., Dhall, R., Narang, S., \& Rawat, S. (2020). The Outbreak of COVID-19 and Stock Market Responses: An Event Study and Panel Data Analysis for G-20 Countries. Global Business Review. http://dx.doi.org/10.1177/0972150920957274

World Health Organization. (2020). Coronavirus. Retrieved from https://www.who.int/healthtopics/coronavirus\#tab=tab_1

Worldometer. (2020). covid-19 Coronavirus Pandemic. Retrieved from https://www.worldometers.info/coronavirus/\#countries

Zeren, F., \& Hizarci, A. (2020). A. The Impact of Covid-19 Coronavirus on Stock Markets: Evidence from Selected Countries. Muhasebe ve Finans Incelemeleri Dergisi, 3(1), 78-84. http://dx.doi.org/10.32951/mufider.706159

\section{Copyright}

This article is an open access article distributed under the terms and conditions of the Creative Commons Attribution-NonCommercial-NoDerivatives 4.0 International License. 